\title{
Penanganan Pasien Perdarahan Intraserebral di Ruang Rawat Intensif
}

\author{
Rian C. Ibrahim, ${ }^{1}$ Diana Ch. Lalenoh, ${ }^{2}$ Mordekhai L. Laihad ${ }^{2}$
}

\author{
${ }^{1}$ Program Studi Pendidikan Dokter Fakultas Kedokteran Universitas Sam Ratulangi, Manado, \\ Sulawesi Utara, Indonesia \\ ${ }^{2}$ Bagian Anestesiologi dan Terapi Intensif Fakultas Kedokteran Universitas Sam Ratulangi, \\ Manado, Sulawesi Utara, Indonesia \\ Email: chandrarianibrahim@gmail.com
}

\begin{abstract}
Intracerebral haemorrhage is a type of intracranial haemorrhage that occurs due to rupture of blood vessels in the brain tissue which is caused by trauma, hypertension, and nonhypertension. The intensive care unit is a separate section within the hospital that treats patients with life-threatening conditions, undergoing resuscitation, requiring intensive care and monitoring, and containing equipment and medicines to maintain normal body functions. All patients who are treated with intracerebral haemorrhage in intensive care unit should receive attention in terms of radiological evaluation, maintaining adequate respiration and circulation, controlling intracranial pressure, controlling blood pressure, preventing hyperglycemia, hypotension, and fever, controlling neurosurgical surgeries as well as preventing seizures. Surgery is performed to evacuate the accessible hematoma, depending on the location of the hematoma in intracerebral. In general, management of the patients aims to minimize nerve damage, prevent and treat systemic complications, speed recovery, and prevent or slow down recurrences and complications. Outcome of patient with intracerebral haemorrhage will be better if the patient is treated specifically in the intensive care unit.
\end{abstract}

Keywords: management, intracerebral haemorrhage, intensive care unit

\begin{abstract}
Abstrak: Perdarahan intraserebral terjadi akibat robeknya pembuluh darah dalam jaringan otak yang dapat disebabkan oleh trauma, hipertensi, dan non hipertensi. Ruang rawat intensif merupakan bagian tersendiri di dalam rumah sakit yang merawat pasien dengan kondisi mengancam jiwa, yang sedang menjalani resusitasi, membutuhkan perawatan dan pemantauan secara intensif, serta yang didalamnya terdapat peralatan maupun obat-obatan yang berguna untuk menjaga fungsi tubuh seperti normal. Semua penderita yang dirawat dengan perdarahan intraserebral di ruang rawat intensif harus mendapat perhatian dalam hal evaluasi radiologik, menjaga adekuatnya respirasi dan sirkulasi, pengendalian tekanan intrakranial, pengendalian tekanan darah, pencegahan hiperglikemi, hipotensi dan demam, pengontrolan terhadap operasi pembedahan saraf dan pencegahan kejang. Pembedahan dilakukan untuk evakuasi hematom yang dapat dijangkau, tergantung lokasi hematoma di intraserebral. Penanganan yang dilakukan bertujuan untuk meminimalkan kerusakan saraf, mencegah dan mengobati komplikasi sistemik yang terjadi, mempercepat pemulihan dan mencegah atau memperlambat kekambuhan dan komplikasi. Outcome pasien perdarahan intraserebral akan lebih baik, jika pasien dirawat khusus di ruang rawat intensif.
\end{abstract}

Kata kunci: penanganan, perdarahan intrasereberal, ruang rawat intensif

\section{PENDAHULUAN}

Stroke hemoragik merupakan pecahnya pembuluh darah otak yang menyebabkan keluarnya darah ke jaringan parenkim otak, ruang serebrospinal disekitar otak, atau kombinasi keduanya. ${ }^{1}$ Stroke hemoragik dapat diklasifikasikan berdasarkan lokasi perdarahannya, yaitu: perdarahan subarak- 
noid, perdarahan intraserebral, perdarahan epidural, dan perdarahan subdural. ${ }^{2}$

Perdarahan intraserebral traumatik terjadi pada $8 \%$ pasien dengan trauma kepala dan 13-35\% pada trauma kepala berat. ${ }^{3}$ Menurut World Health Organization (WHO), pada tahun 2006 terdapat 15 juta populasi yang terserang stroke setiap tahunnya di seluruh dunia dan terbanyak ialah usia tua dengan kematian rerata setiap 10 tahun ialah usia antara 55-85 tahun. ${ }^{4}$ Setiap tahunnya terdapat 100.000 orang terserang stroke hemoragik di Amerika Serikat. ${ }^{5}$ Berdasarkan data WHO pada tahun 2015, stroke merupakan penyebab kematian tertinggi kedua di dunia. ${ }^{6}$ Riset Kesehatan Dasar (Riskesdas) Kementerian Kesehatan (Kemenkes) RI tahun 2018 menyatakan bahwa prevalensi stroke berdasarkan diagnosis pada penduduk berusia lebih dari 15 tahun ialah $10,85 \% .^{7}$ Berdasarkan data Kemenkes RI tahun 2014, stroke merupakan penyebab kematian tertinggi di Indonesia yakni sebesar $21,1 \%{ }^{6}$

Peningkatan tekanan intrakranial (TIK), yang biasanya berkembang 1-4 hari setelah stroke namun dapat berkembang secara akut dalam beberapa jam, kemudian menyebabkan gagal napas dan penurunan kesadaran. Pasien perdarahan intraserebral yang disertai dengan komplikasi berat harus dirawat di ruang rawat intensif. ${ }^{2}$

Banyaknya kasus perdarahan intraserebral karena trauma maupun nontrauma di berbagai negara termasuk di Indonesia mendorong penulis untuk membahas tentang penanganan pasien perdarahan intraserebral di ruang rawat intensif.

\section{Perdarahan Intraserebral Traumatik}

Perdarahan intraserebral adalah salah satu jenis perdarahan intrakranial yang terjadi akibat robeknya pembuluh darah yang ada dalam jaringan otak. Deteksi darah fokal diakibatkan oleh cedera renggangan atau robekan rotasional terhadap pembuluh darah intraparenkimal otak atau kadang karena cedera penetrans. ${ }^{8}$

Di Amerika, cedera kepala merupakan penyebab kematian terbanyak pada usia 1544 tahun dan merupakan penyebab kematian ketiga untuk keseluruhan kasus. Di negara berkembang seperti Indonesia, cedera kepala berperan pada hampir separuh dari seluruh kematian akibat trauma, mengingat bahwa kepala merupakan bagian yang tersering dan rentan terlibat dalam suatu kecelakaan. $^{9}$

Perdarahan yang terjadi pada memar otak dapat membesar menjadi perdarahan intraserebral. Lebih dari $50 \%$ penderita dengan perdarahan intraserebral disertai hematom epidural atau hematom subdural. ${ }^{9}$

Selain robekan terbuka yang dapat langsung terjadi karena benturan atau tarikan akibat trauma pada pembuluh darah, dapat juga timbul kelemahan dinding arteri. Bagian ini kemudian berkembang menjadi suatu aneurisma. Aneurisma arteri karotis terletak pada tempat masuknya di dasar tengkorak. Aneurisma pasca traumatik ini bisa terdapat di semua arteri, dan potensial untuk nantinya menimbulkan perdarahan subaraknoid. Robekan langsung pembuluh darah akibat gaya geseran antar jaringan di otak sewaktu trauma akan menyebabkan perdarahan subaraknoid maupun intraserebral. ${ }^{10,11}$

Perdarahan dapat mengisi ventrikel atau hematom yang merusak jaringan. Darah dan bahan vasoaktif yang dilepas mendorong terjadinya spasme arteri, yang berakibat menurunnya perfusi serebral. Spasme arteri atau vasospasme merupakan komplikasi yang serius yang bisa berakibat terjadinya penurunan fokal neurologis, iskemi otak, dan infark. ${ }^{9}$

Cedera kepala diklasifikasikan ke dalam cedera primer dan cedera sekunder. Klasifikasi ini berguna untuk pertimbangan terapi. Cedera primer adalah kerusakan yang ditimbulkan oleh impak mekanis dan stres aselerasi-deselerasi pada tulang kepala dan jaringan otak, mengakibatkan patah tulang kepala (tulang kepala atau basis kranii) dan lesi intrakranial. Selanjutnya, lesi intrakranial diklasifikasikan kedalam dua tipe yaitu cedera difus dan fokal. Terdapat dua kategori cedera difus yaitu brain concussion (bila hilangnya kesadaran berakhir $<6$ jam) dan diffuse axonal injury (bila hilangnya kesadaran berakhir $>6$ jam). Cedera fokal 
terdiri dari beberapa jenis, antara lain brain contusion, hematom epidural, hematom subdural, dan hematom intraserebral (Gambar 1). Cedera sekunder berkembang dalam menit, jam, atau hari sejak cedera pertama dan menimbulkan kerusakan lanjut dari jaringan saraf. Penyebab paling umum dari cedera sekunder ialah hipoksia dan iskemi serebral. ${ }^{11}$

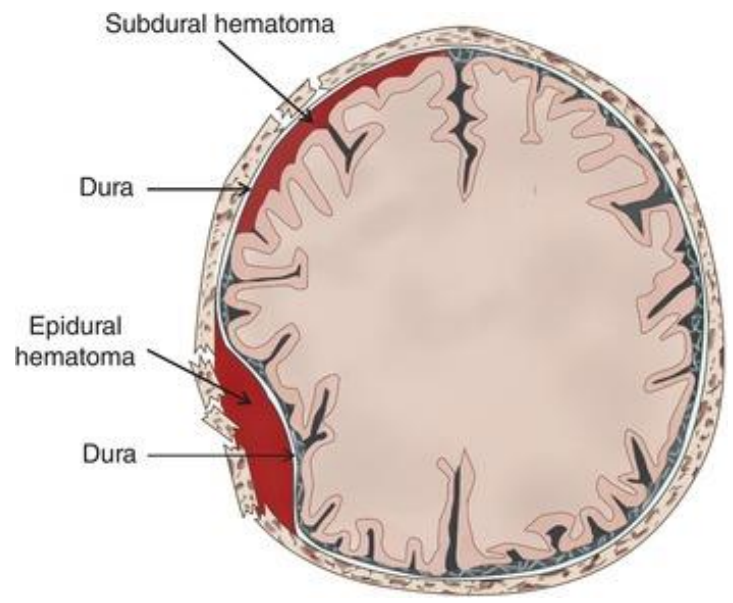

Gambar 1. Perdarahan intraserebral traumatik. Sumber: Zada dan Matsushima, 2015 ${ }^{12}$

Gejala yang sering tampak pada perdarahan intraserebral yaitu penurunan kesadaran atau bertahap seiring dengan membesarnya perdarahan, pola pernapasan dapat secara progresif menjadi abnormal, respon pupil tidak ada, muntah-muntah akibat peningkatan tekanan intrakranial, perubahan perilaku kognitif, dan perubahan fisik pada berbicara dan gerakan motorik dapat timbul segera atau perlahan. Nyeri kepala dapat muncul segera atau bertahap seiring dengan peningkatan tekanan intra-kranial. ${ }^{13}$

Pada pemeriksaan fisik, beberapa hal yang perlu di observasi yaitu tanda-tanda vital. Tekanan darah perlu diperiksa sesering mungkin dan dimonitor secara berkelanjutan, kesadaran dinilai dengan Glasgow Coma Scale (GCS), dan pemeriksaan neurologik. ${ }^{3,14}$ Berdasarkan beratnya, cedera kepala dapat dikelompokkan menjadi: cedera kepala berat (nilai GCS $\leq 8$ ); cedera kepala sedang (nilai GCS 9-13); dan cedera kepala ringan (nilai GCS 14-15). Pemeriksaan GCS sangat membantu untuk menentukan ada tidaknya defisit fokal atau tanda-tanda peningkatan tekanan intrakranial. ${ }^{3,14}$

Prinsip penanganan awal meliputi survei primer dan survei sekunder. Dalam penatalaksanaan survei primer yang diprioritaskan antara lain airway, breathing, circulation, disability dan exposure yang kemudian dilanjutkan dengan resusitasi. ${ }^{15}$

Terapi medikamentosa pada penderita cedera kepala dilakukan untuk memberikan suasana yang optimal untuk kesembuhan. Hal-hal yang dilakukan dalam terapi ini dapat berupa pemberian cairan intravena, hiperventilasi, pemberian manitol, steroid, furosemide, barbiturat dan antikonvulsan. ${ }^{9}$

Mortalitas tertinggi dari hipertensi intrakranial terlihat pada pasien dengan cedera kepala berat. ${ }^{16}$ Pengobatan hipertensi intrakranial ialah posisi kepala dinaikkan $15^{0}$ sampai $30^{\circ}$, mengendalikan kejang, ventilasi $\mathrm{PaCO}_{2}$ normal rendah $(35 \mathrm{mmHg}$ ), suhu tubuh normal, tidak ada obstruksi drainase vena jugularis, optimal resusitasi cairan dan semua homeostasis fisiologik, serta pemberian sedasi dan obat pelumpuh otot bila diperlukan. Bila tindakan ini gagal untuk menurunkan tekanan intrakranial, tambahan terapi diberikan dalam manuver first-tier dan second-tier terapi. ${ }^{11}$

First-tier terapi terdiri dari: 1) drainase cairan serebrospinal secara inkremental melalui kateter intraventricular, 2) diuresis dengan manitol, 0,25-1,5 $\mathrm{g} / \mathrm{kg}$ diberikan lebih dari 10 menit, dan 3) hiperventilasi moderat. Terapi second-tier dilakukan bila peningkatan TIK refrakter terhadap terapi first-tier. Peningkatan TIK refrakter ialah peningkatan TIK secara spontan $>15$ menit dalam periode 1 jam, walaupun telah dilakukan intervensi first-tier secara optimum. Tindakan second-tier terapi adalah hiperventilasi untuk mencapai $\mathrm{PaCO}_{2}<30$ $\mathrm{mmHg}$, dosis tinggi terapi barbiturat, hipotermia, dan kraniektomi dekompresif. ${ }^{16}$

Pada penanganan beberapa kasus cedera kepala diperlukan tindakan pembedahan bila ditemukan perdarahan $>30 \mathrm{ml}$, midline shift $>5 \mathrm{~mm}$, fraktur tengkorak terbuka, dan fraktur tengkorak depres dengan kedalaman $>1 \mathrm{~cm}$. Trepanasi adalah suatu tindakan membuka tulang kepala yang 
bertujuan mencapai otak untuk tindakan pembedahan definitif..$^{9,13}$

\section{Perdarahan Intraserebral}

Menurut National Institute of Neurological Disorder and Stroke (NINDS) stroke adalah adanya defisit neurologik baik fokal maupun global yang terjadi mendadak yang disebabkan oleh gangguan pembuluh darah otak, dalam hal ini terjadi pecahnya pembuluh darah serebri dalam parenkim otak. ${ }^{2,19}$ Perdarahan intraserebral terbagi menjadi intraserebral primer (hipertensi) dan perdarahan intraserebral sekunder (non hipertensi). ${ }^{2,8,17,18}$

Perdarahan intraserebral non hipertensi dapat disebabkan oleh malformasi arteri vena, aneurisma, angiopati amiloid, tumor otak, penyalahgunaan obat, diskrasia darah, antikoagulan, trombolitik, dan vaskulitis. Perdarahan intraserebral hipertensi adalah perdarahan intraserebral dengan hipertensi sebagai penyebab utamanya, terutama hipertensi yang tidak terkontrol, yang menyebabkan rusaknya pembuluh darah kecil di otak sehingga mudah ruptur. Perdarahan ini terdapat di area yang diperdarahi oleh arteri kecil seperti pada talamus, putamen, substansi alba, pons, dan serebelum. ${ }^{2,8,17,18}$

Pada individu normal terdapat sistem autoregulasi arteri serebral, yaitu bila tekanan darah sistemik meningkat maka pembuluh serebral akan mengadakan vasokonstriksi, sebaliknya bila tekanan darah sistemik menurun maka pembuluh serebral akan bervasodilatasi; dengan demikian aliran darah ke otak tetap konstan. Batas atas tekanan darah sistemik ialah tekanan darah sistolik 150-200 mmHg dan diastolik 110$120 \mathrm{mmHg}$. Ketika tekanan darah sistemik meningkat, pembuluh serebral akan berkonstriksi, namun bila keadaan ini terjadi selama berbulan-bulan atau bertahun-tahun, maka akan menyebabkan degenerasi lapisan otot pembuluh serebral, yang selanjutnya menyebabkan pembuluh diameter lumen pembuluh darah menjadi sulit berubah. $2,8,17,18$

Pada hipertensi kronis, pembuluh darah arteriol akan mengalami perubahan dege- neratif yang menyebabkan dinding pembuluh darah arteriol menjadi lemah sehingga akan menimbulkan mikroaneurisma yang tersebar disepanjang pembuluh darah yang disebut sebagai mikroaneurisma CharchotBouchard, yang berbentuk seperti kantung, menonjol melalui tunika media yang lemah. $2,8,17,18$

Menurut Kaplan (1990), jika terjadi peningkatan tekanan darah kronis maka akan menyebabkan kerusakan spesifik pembuluh darah melalui tiga mekanisme yang saling berhubungan, yaitu: pulsatile flow, endothelial denudation, dan replikasi sel otot polos. Namun, yang dapat menyebabkan perdarahan intraserebral ialah mekanisme pulsatile flow, dimana tekanan darah yang tinggi akan menyebabkan tekanan pada jaringan kolagen dan elastin dinding pembuluh darah sehingga terjadi kerusakan berupa medionekrosis, aneurisma, dan perdarahan. ${ }^{2,8,17,18}$

Bila pembuluh darah pecah maka akan terjadi perdarahan atau hematom sampai dengan maksimal 6 jam, yang akan berhenti sendiri akibat pembentukan bekuan darah dan ditampon oleh jaringan sekitarnya. Jika perdarahan terus berlanjut dengan volume yang besar maka akan merusak struktur anatomi otak, ditambah lagi terjadinya edema awal disekitar hematom akibat pelepasan dan akumulasi protein serum aktif osmotik dari bekuan darah. Akibatnya akan terjadi destruksi massa otak dan peninggian tekanan intrakranial yang menyebabkan tekanan perfusi otak menurun serta terganggunya aliran darah otak. Proses ini akan berlanjut dengan terjadinya kaskade iskemik dan edema sitotoksik yang akan menyebabkan kematian sel otak, dan massa di dalam otak akan bertambah sehingga terjadi herniasi otak yang dapat menyebabkan kematian. $^{2,8,17-19}$

Tujuan terapi perdarahan intraserebral antara lain: mencegah akibat buruk dari peningkatan tekanan intracranial, mencegah komplikasi sekunder akibat menurunnya kesadaran, misalnya gangguan pernapasan, aspirasi, hipoventilasi, dan identifikasi sumber perdarahan yang mungkin dapat diperbaiki dengan tindakan bedah. ${ }^{2}$ 


\section{Ruang Rawat Intensif}

Ruang rawat intensif merupakan bagian tersendiri di dalam rumah sakit yang merawat pasien dengan kondisi mengancam jiwa, sedang menjalani resusitasi, membutuhkan perawatan dan pemantauan secara intensif, serta yang di dalamnya terdapat peralatan maupun obat-obatan yang berguna untuk menjaga fungsi tubuh mendekati normal. ${ }^{20}$

Perdarahan intraserebral harus dirawat di ruang perawatan intensif karena dibutuhkan pemantauan dan penanganan secara intensif untuk mencegah kerusakan otak yang lebih luas atau komplikasi lain. ${ }^{21}$ Semua penderita yang dirawat dengan perdarahan intraserebral di ruang rawat intensif harus mendapat perhatian dalam hal evaluasi radiologik, menjaga adekuatnya respirasi dan sirkulasi, pengendalian tekanan darah, pencegahan hiperglikemi, hipotensi dan demam, pengendalian tekanan intrakranial, pengontrolan operasi pembedahan saraf, dan pencegahan kejang. ${ }^{22}$

Segera setelah diagnosis ditegakkan lokasi dan besarnya hematoma maka dilakukan penanganan yang dapat berupa penanganan secara medikal atau pembedahan. Penanganan pada peningkatan tekanan intrakranial antara lain meliputi posisi kepala ditinggikan $30^{\circ}$, cegah batuk dan mengedan, pemberian infus diuretik manitol dan furosemid, serta hiperventilasi dengan mempertahankan EtCO2 normokapnia. ${ }^{22}$

\section{Posisi kepala dan leher}

Posisi kepala harus diatur lebih tinggi sekitar $30^{\circ}-45^{\circ}$ dengan tujuan memperbaiki venous return. Hal ini memperbaiki drainase vena, perfusi serebral dan menurunkan tekanan intrakranial. ${ }^{20}$

\section{Ventilasi dan oksigenasi}

Hipoksia dan hiperkapnia dapat menyebabkan peningkatan volume darah otak dan hipertensi intrakranial. Intubasi dan ventilasi mekanik diindikasikan jika ventilasi atau oksigenasi tidak cukup pada pasien dengan edema otak. Setelah pasien diintubasi, pengaturan ventilator harus disesuaikan untuk mempertahankan PO2 normal dan PCO2. ${ }^{23}$
Perlindungan jalan napas pada pasien stroke memerlukan intervensi yang harus segera dilakukan. Perburukan keadaan pasien stroke seperti adanya peningkatan TIK, gangguan di pusat respiratorik yakni apnea, paralisis otot faring dan lidah yang mengakibatkan obstruksi jalan napas, serta penurunan kesadaran merupakan indikasi untuk diintubasi dan pemasangan ventilasi mekanik. $^{24}$ Intubasi diindikasikan pada insufisensi ventilasi yang ditunjukkan oleh adanya hipoksia (pO2 $<60 \mathrm{~mm} \mathrm{Hg}$ atau $\mathrm{PCO} 2>50 \mathrm{~mm} \mathrm{Hg}$ ) atau risiko aspirasi yang jelas dengan/tanpa gangguan oksigenasi arterial. ${ }^{25}$

\section{Hiperventilasi}

Hiperventilasi merupakan salah satu cara efektif untuk mengontrol peninggian tekanan intrakranial dalam 24 jam pertama. Hal ini bermanfaat agar daerah iskemi akan berperfusi baik. Bila $\mathrm{PaCO}_{2}<20 \mathrm{mmHg}$, aliran darah akan makin turun sehingga oksigen di otak tidak cukup tersedia. Iskemi serebral akibat peningkatan TIK bisa pulih, namun diganti oleh iskemi serebral karena vasokontriksi pembuluh darah serebri. ${ }^{26}$

\section{Terapi cairan}

Kebutuhan cairan isotonik seperti $\mathrm{NaCl}$ $0,9 \%$ sekitar $1 \mathrm{ml} / \mathrm{kg} / \mathrm{jam}$, harus diberikan pada pasien sebagai standar cairan agar mendapatkan kondisi yang euvolemik dan diuresis setiap jam harus lebih dari $0,5 \mathrm{cc} / \mathrm{kgbb}$. Pemberian cairan $\mathrm{NaCl} 0,45 \%$ atau dextrose $5 \%$ dapat memperberat edema serebral dan meningkatkan TIK karena terjadi perbedaan osmolaritas, yang menyebabkan cairan berpindah ke jaringan otak yang cedera. Hipo-osmolaritas sistemik $(<280 \mathrm{mOsm} / \mathrm{L})$ harus diterapi agresif dengan manitol atau salin hipertonik $3 \% .{ }^{27}$ Tujuan pemberian salin hipertonik selain sebagai resusitasi cairan juga mempertahankan osmolaritas agar tetap hiperosmolar (300-320mOsms/L) dan hipernatremi (150-155mEq/L) yang dapat mengurangi bengkaknya sel. ${ }^{28}$

\section{Terapi tekanan darah}

American Heart Association (AHA) 
telah membuat pedoman bahwa tekanan darah sistolik lebih dari $180 \mathrm{mmHg}$ atau MAP lebih dari $130 \mathrm{mmHg}$ harus diterapi dengan infus obat antihipertensi terus menerus seperti labetalol, esmolol, atau nikardipin, sedangkan terapi oral dan sublingual sudah tidak menjadi pilihan lagi. Pada umumnya tidak bermasalah dengan tingginya tekanan darah, tetapi MAP harus tidak boleh berkurang $15-30 \%$ selama 24 jam pertama. ${ }^{27}$

\section{Terapi diuretika}

Penurunan TIK yang cepat dapat dicapai dengan pemberian diuretik. ${ }^{26}$ Dua macam diuretika yang umum digunakan yaitu osmotik diuretik manitol dan loop diuretik furosemide. Manitol diberikan secara bolus intravena dengan dosis 0,25 sampai $0,5 \mathrm{gram} / \mathrm{kgBB}$ setiap 4 jam dan furosemid $10 \mathrm{mg}$ setiap 2 sampai 8 jam. ${ }^{27,28}$

\section{Pencegahan kejang, demam, dan hiper- glikemia}

Pencegahan kejang akut harus dilakukan dengan pemberian fenitoin $17 \mathrm{mg} / \mathrm{kgBB}$ sebagai loading dose kemudian $100 \mathrm{mg}$ setiap 8 jam. AHA memberi rekomendasi bahwa pemberian anti-epileptik diberikan sampai 1 bulan setelah bebas dari kejang. ${ }^{27}$

Demam atau suhu $>38,3^{\circ} \mathrm{C}$ pada pasien perdarahan intraserebral sering ditemui. Demam yang tetap terjadi setelah perdarahan intraserebal memperlihatkan outcome yang buruk. Hipertermi dapat memperburuk iskemia otak yang telah mengalami cedera dengan melepaskan neurotransmiter eksitotoksik, proteolisis, radikal bebas dan produksi sitokin, blood-brain barrier compromise, dan apoptosis. Selain itu juga terjadi hipertemia, bertambahnya edema otak, dan meningkatnya TIK. Standar umum untuk pasien dengan suhu $>38,3^{\circ} \mathrm{C}$, diterapi dengan acetaminophen dan cooling blankets. ${ }^{27}$

Hiperglikemi merupakan suatu prediktor poten terhadap kematian dalam 30 hari, pada pasien diabetik atau non-diabetik dengan perdarahan intraserebral. ${ }^{27}$

\section{Terapi hipotermia}

Hipotermi lebih efektif bila dimulai lebih awal setelah onset gejala. Hipotermi yang dimulai 90-120 menit menunjukkan angka ketahanan hidup yang lebih tinggi dan luaran fungsional yang lebih baik dibanding normotermi. Secara umum, hipotermi dibagi menjadi hipotermi berat (suhu $<28^{\circ} \mathrm{C}$ ), hipotermi sedang/moderat (suhu $28-33^{\circ} \mathrm{C}$ ), dan hipotermi ringan (suhu $33-36^{\circ} \mathrm{C}$ ). Saat ini, kebanyakan penelitian menggunakan hipotermi ringan hingga sedang karena efek samping hipotermia seperti hipokalemia, gangguan irama dan konduksi jantung, komplikasi infeksi, dan koagulopati. ${ }^{29}$

\section{Simpulan}

Perdarahan intraserebral merupakan penyakit berat dengan sejumlah faktor yang memengaruhi outcome klinis dan gejala sisanya. Diperlukan pemahaman secara teliti mengenai setiap aspek penyakit ini dan kemungkinan komplikasi yang dapat terjadi. Tujuan umum ialah meminimalkan kerusakan saraf, mencegah dan mengobati komplikasi sistemik yang terjadi, mempercepat pemulihan dan mencegah atau memperlambat kekambuhan dan komplikasi. Outcome pasien perdarahan intraserebral akan lebih baik, jika pasien dirawat khusus di ruang rawat intensif. ${ }^{23}$

\section{Konflik Kepentingan}

Penulis menyatakan tidak terdapat konflik kepentingan dalam studi ini.

\section{DAFTAR PUSTAKA}

1. Goetz CG. Neurologi Klinik (3rd ed). Philadelphia: Saunders, 2007.

2. Goldszmidt AJ, Caplan LR. Stroke Esensial. (2nd ed). Jakarta: Indeks, 2013; p. 3644, 46-9.

3. Greenberg MS (edt), Handbook of Neurosurgery (7th ed). New York: Thieme, 2010.

4. Caplan LR. Caplan's Stroke: A Clinical Approach (3rd ed). Boston: Butterworth-Heinemann, 2000.

5. Mursyid B. Manajemen Stroke Komprehensif. Yogyakarta: Pustaka Cendekia, 2007.

6. Kemenkes RI. Kebijakan dan Strategi Pencegahan dan Pengendalian Stroke di Indonesia. 2017. [cited 2020 Feb 27]. Available from http://p2ptm.kemkes. 
go.id/uploads/VHcrbkVobjRzUDN3U Cs4eUJOdVBndz09/2017/10/Kebijakan _dan_Strategi_Pencegahan_dan_Penge ndalian_Stroke_di_Indonesia_dr_Lily_ Sriwahyuni_Sulistyowati_MM1.pdf

7. Kemenkes RI. Hasil Utama Riset kesehatan dasar 2018. [cited 2020 Feb 27]. Available from: http://www.kesmas. kemkes.go.id/assets/upload/dir_519d41 d8cd98f00/files/Hasil-riskesdas-2018_ 1274.pdf

8. Keep RF, Hua Y, Xi G. Intracerebral haemorrhage: mechanisms of injury and therapeutic targets. Lancet Neurol. 2012; 11(8):2-10.

9. Listiono LD. Cedera kepala. In: Ilmu Bedah Saraf (3rd ed). Jakarta: Gramedia Pustaka Utama, 1998; p.164-9.

10. Povlishock JT, Bullock MR. Guidelines for management of severe traumatic brain injury. J Neurotrauma. 2007;24(1):100-6.

11. Lalenoh DC, Sudjito MH, Suryono B. Penanganan anestesi pada cedera otak traumatik. JNI. 2012;1(2):120-32.

12. Zada G, Matsushima K. Atlas of Surgical Techniques in Trauma. Cambridge: Cambridge University Press, 2015.

13. Reilly P, Bullock R. Head Injury, editors, Pathophysiology and Management of Severe Closed Injury (2nd ed). London: CRC Press, 2005.

14. Sjamsuhidajat, R. Sistem saraf. In: Ilmu Bedah (2nd ed). Jakarta: EGC, 1998; p. 817-21.

15. Ngoerah IGN. Trauma pada susunan saraf. In: Dasar-dasar Ilmu Bedah Saraf. Jakarta: ECG, 1996; p. 312.

16. Bisri DY, Bisri T. Pengelolaan hipertensi intrakranial yang membandel pada cedera otak traumatik. JNI. 2018;7(2): 126-33.

17. Ropper AH, Brown RH. Cerebrovascular diseases. In: Adam and Victor's Principles of Neurology (8th ed). New York: Mc Graw-Hill, 2005.
18. Aminoff MJ, Greenberg DA, Simon RP. Clinical Neurology (7th ed). San Fransisco: McGraw-Hill, 2009.

19. Jones HR. Netter's Neurology (Netter Clinical Science) (2nd ed). Philadelphia: WB Saunders, 2011.

20. Norris J, Hachinski V. Intensive Care Management of Stroke Patients. 2015. [cited 2020 April 7]. Available from: http://stroke.ahajournals.org

21. Morawo AO, Gilmore EJ. Critical care management of intracerebral hemorrhage. Semin Neurol. 2016;36(03): 225-32.

22. Muhammad AR, Umar N, Saleh SC. Penatalaksanaan anestesi pada perdarahan intraserebral yang disebabkan stroke hipertensi. JNI. 2012;1(3):203-8.

23. Rabinstein AA. Treatment of Cerebral Edema. The Neurologist. 2006;12:59-73.

24. Fahmi I, Gamefianty A, Nurachmah E. Manajemen hipotermia pada pasien cedera kepala : suatu tinjauan literatur. Forikes. 2019;10(3):199-202.

25. Cahyo M, Nazaruddin A, Rasmin $M$, Prasenohadi, Sidharta IDK, Lolong Wulung NGHM, et al. Pengaruh tindakan kraniotomi pada penggunaan ventilasi mekanis dan lama perawatan intensif pada pasien stroke hemoragis di Unit Perawatan Intensif RS Persahabatan. J Respir Indo. 2012;2(32):101-3.

26. Affandi IG, Panggabean R. Pengelolaan tekanan tinggi intrakranial pada stroke. CDK. 2016;3(43):180-3.

27. Satriyanto MD, Saleh SC. Tatalaksana anestesi pada pendarahan intraserebral spontan/non trauma. JNI. 2012;1(4):1-8.

28. Mangastuti RS, Oetoro BJ, Sudadi. Penatalaksanaan anestesi pada pasien stroke hemoragik. JNI. 2014;3 (2): 80-7.

29. Syah BIA, Fuadi I, Rahardjo S. Terapi hipotermia pada stroke hemoragik. JNI. 2015;4(1):61-8. 